\title{
農家の自家製みそおよびしょう油に着生する 有害系状菌の検索について
}

. (昭 和 45 年 6 月 9 日 受 理)

$\begin{array}{lll}\text { 山崎幹夫* } & \text { 堀江義一* } & \text { 藤本治宏* } \\ \text { 鈴木重紀* } & \text { 崊原洋于* } & \text { 宮木高明* }\end{array}$

On the Toxigenic Fungi Contaminating Home-made Miso and Soy Sauce.

Mikio YAMAZAKI*, Yoshikazu HORIE*, Haruhiro FUJIMOTO*, Shigetoshi SUZUKI*, Yoko SAKAKIBARA* and Komei MIYAKI*

(*Department of Mycological Sciences, Institute of Food Microbiology, Chiba University, 3-9-1, Izumi-cho, Narashino, Chiba)

\begin{abstract}
The investigation on the toxigenic fungi contaminating home-made miso and soy sauce was carried out. A strongly toxic strain of Aspergillus ochraceus and two toxic strains of Penicillium cyclopium were found as a result of the investigation in which 46 samples of miso and 11 samples of soy sauce collected in Tohoku district were examined. The production of ochratoxin A in Aspergillus ochraceus was recognized by thin layer chromatography and the toxicity bioassay with chicken embryo and mouse.
\end{abstract}

(Received June 9, 1970)

緒 言

Aspergillus flavus によって 産生される aflatoxin'1 の強い毒性扣よび発癌性が発見されて以来, 食品に着生 する有害かびの問題が強く注目されるよらになった．当 然わが国の発酵工業生産物に対する調査研究も行なわれ たが，現在まで，わが国の発酵食品に利用されるこらじ 菌より aflatoxin が分離されたという報告はない2).し かし最近，倉田ら ${ }^{8)}$ は長野県佐久市付近で採取した自家 製みそより, aflatoxin 産生能を有寸る Aspergillus flavus 1 株を分離したことを報告している.

今回, われわれは東北地方の農家において自家醇造さ れたみそ 46 検体, し上5油 11 検体を採集し, 着生す るカビの分布, および 毒性を調べた 結果, 毒性の強い Aspergillus ochraceus 1 株を分離し，本株に扣ける ochratoxin A 産生能を確認したほか, マウスおよび鵎 胚に対して毒性を有する Penicillium cyclopium 2 株 を認めたので報告する.

\section{実跧材料むよひ方法}

1. 試料：主として東北地方の婛家に貯蔵された自 家醸造みそおよびしょ5油を1969 年6月に採集し冷蔵

* 千葉大学腐敗研究所有害真菌研究部 習志野市泉町 3-9-1.

\begin{tabular}{|c|c|c|c|c|}
\hline \multirow{2}{*}{ 酸 } & \multirow{2}{*}{ 造 } & \multirow{2}{*}{ 年 } & \multicolumn{2}{|c|}{ 検 体 数 } \\
\hline & & & み そ & しょら油 \\
\hline 昭和 & 34 & 年 & 3 & 2 \\
\hline & 35 & 年 & 0 & 0 \\
\hline & 36 & 年 & 6 & 2 \\
\hline & 37 & 年 & 1 & 1 \\
\hline & 38 & 年 & 5 & 0 \\
\hline & 39 & 年 & 4 & 4 \\
\hline & 40 & 年 & 3 & 0 \\
\hline & 41 & 年 & 13 & 1 \\
\hline & 42 & 年 & 8 & 0 \\
\hline & 43 & 年 & 0 & 0 \\
\hline & 44 & 年 & 3 & 1 \\
\hline 合 & & 計 & 46 & 11 \\
\hline
\end{tabular}

保存したのち，1970 年 1 2 月に検査を実施した.

2. 菌の分離: みそ, しょら油ともに $10 \mathrm{~g}$ を科取 し, $0.02 \%$ 隇菌寒天溶液 $40 \mathrm{ml}$ 中にまぜ, ガラスビー ズとともに振ってよく溶かす. その $1 \mathrm{ml}$ をとり,さら に $0.05 \%$ 隇菌寒天溶液によって10倍に希釈した溶液の 1 
$\mathrm{ml}$ をシャーレに流し,かたまりかけた下記組成の malt 加塩寒天培地 $20 \mathrm{ml}$ とまぜ, $25^{\circ} て ゙ 10$ 日間培荃を行なっ た.

Malt 加塩寒天培地
malt extr. $20.0 \mathrm{~g}$
$\begin{array}{lr}\text { 食 塩 } & 75.0 \mathrm{~g} \\ \text { 寒 } & 20.0 \mathrm{~g} \\ \text { 蒸留水 } \quad 1000 \mathrm{ml}\end{array}$

生育した菌集落からクロラムフェニコールを添加した potato dextrose agar 料面培地に釣菌分離した，同定 にあたっては, Czapek 寒天, 20\% sucrose 添加 Czapek 寒天, malt extr. 寒天などを用い, Raper および Thom4), Raper および Fennell5) 等による記載を参照 した.

3. 分離菌の培養および抽出エキスの製作： $500 \mathrm{ml}$ の Erlenmeyer フラスコに精白米 $50 \mathrm{~g}$ 水 $25 \mathrm{ml}$ を入 れ, 高圧减菌 $\left(120^{\circ}, 20\right.$ 分間) の後 malt 寒天斜面培地 に前培養した菌を接種， $27^{\circ}$ にて 9 日間時々振とらしな がら静置培養した．培養終了後各フラスコにクロロホル ム $250 \mathrm{ml}$ ずつを加え, 振とらして抽出, 溶媒を酢酸工 チルに変え, さらに $300 \mathrm{ml}$ ずつ2 3回の振と5抽出を 行ない，抽出液を合わせ，低温下溶媒を除去して抽出エ キスを得た。

4. 棒性の検索：抽出エキスをプロピレングリコー ル (PG) に溶解させ, $10 \mathrm{mg} / 0.1 \mathrm{ml} \mathrm{PG}$ のエキスがマ ウスー匹あたりに投与されるように濃度を調製, ddys 系雄マウス（5 週令, 平均体重 $23 \mathrm{~g}$ ) に腹腔内注射に上 り投与した．声性の判定は24，48，96時間および 7 日後 の致死率および体重変化の観察によった．また高い致死 率の得られた場合には剖検を実施した。

鷄胚による毒性検定にはエキスの投与量が $1000 \mu \mathrm{g} /$ $0.2 \mathrm{ml} \mathrm{PG} / \mathrm{egg}$ になるよらに濃度を調製した試料液を 受精 5 日後の卵黄のう内に注射し，24，48 時間後の致 死率およびふ化率を観察した。

\section{結 果}

1. 菌分布： 全試料のらち, 菌着生の見られなかっ た試料はみそにはなく，しょら油に 2 例認められた。 た yeast のみが分離され，ほかに菌を分離出来なかった 試料はみそに19，しょう油に 3 例を数えた。発現菌種は 少なく, Aspergillus 6種15侏, Penicillium 4種17株, のほか Candida 2侏, Mucor 1 株, Cladosporium 4 株, Mycelia sterilia 2 株, Penicillium と思われる未 同定株 1 株を数えたに過ぎない. (Table 1)

2. 車性：分離された菌株のらち，とくに aflatoxin 産生の恐れのある Asp. oryzae および Asp. flavus の すべてと，文献上マイコトキシン産生の可能性を有する 菌株については精白米に培養した菌体の酢酸エチル抽出 エキスを作製し，マウスおよび鷄胚に対する毒性を検討 した (Table 2). その結果, Asp. oryzae, Asp. flavus
Table 1. Population of Aspergillus and Peni cillium in Home-made Miso and Soy Sauce.

\begin{tabular}{|c|c|c|c|c|}
\hline \multicolumn{2}{|c|}{ Species } & Miso & $\begin{array}{l}\text { Soy } \\
\text { Sauce }\end{array}$ & Total \\
\hline \multirow[t]{7}{*}{ Aspergillus } & versicalor & 4 & 2 & 6 \\
\hline & oryzae & 3 & 1 & 4 \\
\hline & flavus & 1 & 0 & 1 \\
\hline & ochraceus & 0 & 1 & 1 \\
\hline & repens & 1 & 0 & 1 \\
\hline & umbrosus & 1 & 0 & 1 \\
\hline & penicilloides & 1 & 0 & 1 \\
\hline \multirow[t]{4}{*}{ Penicillium } & puberulum & 6 & 2 & 8 \\
\hline & cyclopium & 5 & 0 & 5 \\
\hline & viridicatum & 2 & 0 & 2 \\
\hline & janthinellum & 2 & 0 & 2 \\
\hline
\end{tabular}

Table 2. Results in Toxicity Bioassay.

\begin{tabular}{l|c|c|c} 
Species & $\begin{array}{c}\text { No. of } \\
\text { strain }\end{array}$ & $\begin{array}{c}\text { No. of toxic strain* } \\
\text { to mice } \\
\text { (ip) }\end{array}$ & $\begin{array}{c}\text { to chicken } \\
\text { embryos }\end{array}$ \\
\hline Asp. $\begin{array}{l}\text { flavus. } \\
\text { ochraceus }\end{array}$ & 4 & $n$ & 0 \\
Pen. cyclopium & 1 & 1 & 1 \\
janthinellum & 1 & 2 & 2 \\
vilidicatum & 1 & 0 & 0 \\
& & 0 & 0
\end{tabular}

* The toxic strains observed were definited as the strain which indicated mortality over $50 \%$ in 96 hours after dosage.

には毒性を有する例が見られなかった。しかし Asp. ochraceus はマウス, 鷄胚共に強い童性を示し, マウス

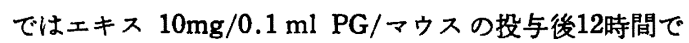
供試マウスの全てを憼死させ, 鷄肧においても $1000 \mu \mathrm{g} /$ egg 投与後 48 時間で 11/14，96 時間で全卵の擎死を見 た.この株からはつぎに述べる化学検索により ochratoxin A の産生が認められた。 またPen. cyclopium は 眝蔵殼類に広く分布し，成分としてラット，あひるひな に対して㽦性を有する cyclopiazonic acid を産生する ことが報告されているが6)，我々の検索に拈いても検索

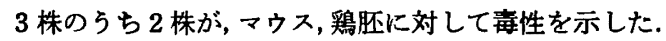
マウスに和ける剖検では各例共に腹膜炎の症状が観察さ れた. Pen. janthinellum と Pen. viridicatum につ いては各 1 株を毒性検索に供試したがいずれも強い走性 を示さなかった。ただし，両例共に鷄肧に対し，48時間 以後に打いて徐々に死亡例が出現し，7 日を経過した段 階においてはいずれす50\%をこえる致死率を示した事が 注目されよう。占化率は Pen. janthinellum で1/13, 
Pen. viridicatum では 3/13 であった.

3. 代韵産物の検宗：Asp. oryzae, Asp. flavus に おける aflatoxin, Asp. ochraceus における ochratoxin の検索は薄層クロマトクララィーによった. Merck のシリカゲルブレート No. $5724(0.25 \mathrm{~mm})$ を用い, aflatoxin については $\mathrm{CHCl}_{8}-\mathrm{MeOH}(24: 1)$, ochratoxin については benzene-MeOH-EtOAC (15: $3: 1)$ の 溶媒系を用い，それぞれ標品と共に展開検索した結果， aflatoxin は検出されず，ochratoxin A が Asp. ochraceus のエキスより検出された. Pen. cyclopiumに ついて cyclopiazonic acid の検索を行なったが, TLC による検索においては本物質は検出されず，ほか に $\mathrm{FeCl}_{\mathbf{3}}$ に呈色するフェノール性物質の存在を認めた が，毒性の本体については確認されていない。

\section{考察}

先に述べたよらに，わが国で大きな比重を占める発酵 食品の生産に利用されるこうじ菌については, すでに広 範な調査研究が行なわれ, 問題となるべきマイコトキシ ンの生産菌は認められなかったことが報告されている. 今回われわれが取りあげた自家醇造みそおよびしょら油 は，現在ではかなりその製造の少なくなっていることは 事実であるが，なお東北地方の一部屡家においてはよく

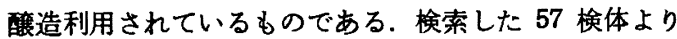
分離された菌種は比較的少なく, Penicillium, Aspergillus, Candida 属等がほとんどであり, 菌数も少なか った. しかし毒性検索においては，Asp. ochraceus， Pen. cyclopium 等に強い毒性を示すものが発見され， とくに Asp. ochraceus から ochratoxin A の産生が 諗められたことは注目に值いしよう。 ochratoxin A は ラットに対しては $20 \sim 22 \mathrm{mg} / \mathrm{kg}^{7)}$, マウスに対しては $45.2 \mathrm{mg} / \mathrm{kg}^{8)}$, 鶏胚に対しては $18.8 \mu \mathrm{g} / \mathrm{egg}^{8)}$ の $\mathrm{LD}_{50}$ 值 を有する南アフリカで発見された マイコトキシンであ り9), われれは米着生菌(10)に，名取らは小豆こしょ ら粉末からの分離菌国に, ochratoxin 生産性の Asp. ochraceus を発見しているが，生産菌がしょ油より分
離されたのは初めてである.なお自家釀造みそおよびし ょう油に関する着生有害系状菌についてはさらに多数の 試料についての検索を続行中であり，結果については続 報したい。

\section{詂 辞}

試料の採取につき御爰助いただいた宮城県衛生部環境 衛生課，試料を提供された農家の方々に感謝いたしま す。また本研究の実施にあたり有益な御助言をいただい た国立衛生試験所倉田 浩, 宇田川俊一両博士に深く感 謝の意を表します．本研究の一部は厚生省がん研究助成 金によったことを合わせ感謝する。

文献

1) B. F. Nesbitt, J. O'kelly, K. Sargeant and A, Sheridan: Nature 195, 1062 (1962).

2) 横塚 保，佐々木正興，他 3 名：日農化誌。41, 32 (1967) および引用文献.

3）倉田 浩，宇田川俊一，他 4 名：第 17 回食品衛 生学会学郝演会要旨 (1969 年 5 月, 東京).

4) K. B. Raper, C. Thom: "A Manual of the Penicillia" (1949) Williams and Wilkins Co., Baltimore.

5) K. B. Raper, D. L. Fennell: "The Genus Aspergillus" (1965), Williams \& Wilkins Co., Baltimore.

6) C. W. Holzapfel: Tetrahedron 24, 210 (1968).

7) I. F. H. Purchase, J. J. Theron: Fd. Cosmet. Toxicol. 6, 479 (1968).

8) M. Yamazaki, S. Suzuki, et al.: Toxical. Appl. Pharmacol. 投稿中.

9) K. J. van der Merwe, P. S. Steyr, et al.: Nature 205, 1112 (1965).

10) M. Yamazaki, Y. Maebayashi, K. Miyaki: Appl. Microbiol. 20, 452 (1970).

11) S. Natori et al.: Chem. Pharm. Bull. 投稿 中.（私信による). 